\title{
ELECTRODIAGNOSIS IN POST-TRAUMATIC SYRINGOMYELIA
}

\author{
By Margarete di Benedetto, M.D.` and Professor Alain B. Rossier, M.D. $\dagger$ \\ * Rehabilitation Medicine Service and $\dagger$ Spinal Cord Injury Service, Veterans Administration \\ Hospital, I400 V.F.W. Parkway, West Roxbury, Mass. 02132, Department of Orthopedic \\ Surgery, Harvard Medical School, U.S.A.
}

Abstract. Development of a syrinx several years post spinal cord trauma is a well-known entity and described in a number of scientific communications. Each one describes the few cases encountered with the clinical presentations; many report results of myelography with positive or negative contrast media, operative procedures, and eventual outcome as well as discussions of autopsy material. It is believed by many investigators and clinicians that surgical intervention frequently stops the progression of the syrinx and sometimes even reverses the symptomatology. Early exact diagnosis is thus paramount.

Electromyography, if used judiciously, may be an important adjunct to proper diagnosis and prognosis. In a patient with previous spinal cord trauma, frequently even post-surgical procedures, the interpretation is often difficult. This paper discusses the electrodiagnostic findings in three patients with post-traumatic syrinx and compares them with electrodiagnostic changes observed in a spinal cord injury patient with increased symptomatology due to other causes and two patients with non-traumatic cervical syringomyelia.

Key words: Syringomyelia; Spinal cord injuries; Nerve conduction-electromyography.

\section{Introduction}

DisSOCIATED sensory loss-thermo-anaesthesia and analgesia-over several cervical segments unilateral, symmetrical or asymmetrical with or without muscle weakness and atrophy are the cardinal symptoms of syringomyelia. Frequently there also is early kyphoscoliosis due to damage of the dorsomedian and ventromedian nuclei. Later upper motor neuron signs in the lower extremities appear and neurogenic bladder and bowel. This fully expressed symptomatology offers little challenge to full recognition. At times, however, there is quite a variance to this symptom complex; even superficial pain and temperature awareness may be intact (Magee \& Schneider, 1967) or dissociated sensory loss may be mimicked by other lesions (Finlayson, 1974). This then presents significant diagnostic problems.

Development of a syrinx after a spinal cord injury mostly begins with pain in the neck, back, arms and/or hands followed by objective motor, sensory and reflex changes (Martin \& Maury, 1964; Barnett et al., 1973). Symptoms often extend up from the previous lower level of injury and lower limb weakness may increase in incomplete lesions. With the frequently existing problems of root irritation, compression syndromes, and muscle strains through faulty and unphysiological body mechanics, early recognition in especially this form of syringomyelia is frequently difficult. The often-observed positive results after surgical intervention compounds the necessity of early, correct diagnosis (Rossier et al., I968; Werner et al., I969; Barnett et al., 1973). This communication hopes to stress the place of electrodiagnostic studies in a proper work-up for such a symptom complex. 


\section{Method and Material}

Six patients presenting with increasing motor and sensory deficits, four of them with typical dissociation, were studied electrodiagnostically in addition to complete clinical examination and myelography. Two patients were diagnosed as 'true' syringomyelia (one congenital and one acquired) and three were previous spinal cord injury patients in whom the diagnosis of a post-traumatic syrinx was made. One additional spinal cord injury patient was found to have only root irritation.

Electrodiagnostic studies consisted of sensory and motor nerve conductions in the median, ulnar, sural, and peroneal nerves and one- and two-channel electromyography was performed. A Teca Model $\mathrm{T}_{4}{ }^{1}$ with a built in stimulator and chronaximeter was used. For stimulation rectangular pulses of 0.1 to $0.2 \mathrm{~ms}$ duration were applied through surface electrodes. Electromyography was performed with coaxial needles, stimulation studies with superficial recording electrodes. Skin temperature was monitored. Strength-duration curves were also done on some of the involved muscles in every patient. The findings of the spinal cord injury patients with post-traumatic syrinx were compared with those found in the 'true' syringomyelia patients and the patient with root irritation.

\section{Review of Patients}

I. Nineteen-year-old white male patient (E. C.) presenting with neck and head pain and weakness in the right arm. There was increased right deep tendon reflexes and Babinski and dissociated sensory loss. Cervical dye myelogram showed widening of the spinal canal from $\mathrm{C}_{2}$ to $\mathrm{C}_{5}$. The patient had a laminectomy performed and an anterior cyst and a low-grade glioma were found. Postoperatively the patient improved in his function. Electrodiagnostic studies showed normal nerve conduction studies. The electromyogram of the right biceps, wrist flexors and first dorsal interosseous revealed an increase in polyphasia and an increase in action potential duration up to $20 \mathrm{~ms}$ (normal 6-12 ms). Amplitudes were up to 4000 microvolts. There was a minor increase in synchronisation on two-channel electromyography. Otherwise findings were within the norm.

2. Forty-eight-year-old white male (B. D.) who had insidious onset of weakness and sensory changes 2I years prior to the examination. He now has absent upper extremity deep tendon reflexes, and the lower extremities show $4+$ knee and ankle jerks bilaterally equal and bilateral Babinski's. The patient has a spastic gait and weakness and atrophy of right hand muscles. There is dissociated sensory loss bilateral from $\mathrm{C}_{4}$ to $\mathrm{T}_{2}$. Electrodiagnostic studies showed normal nerve conduction. There were giant potentials and marked increase in polyphasia in the opponens pollicis, first dorsal interosseous, biceps and deltoid; and two-channel electromyography showed a marked increase of synchronisation in the biceps and brachioradialis.

3. Thirty-two-year-old white male patient (S. W.) who had a $\mathrm{C}_{5}-6$ traumatic myelopathy in 1972 presented with pain in the right side of his neck and increasing weakness and numbness including the face around the mouth 3 years after injury. Dye myelogram was within the norm. Electrodiagnostic studies showed a slight increase of potential duration in the trapezius. Polyphasia was 30 per cent and on maximal effort there was good recruitment. Amplitudes were up to 3000 microvolts. Two-channel EMG showed no increase in synchronisation. The right biceps showed potential duration up to I $4 \mathrm{~ms}$, amplitudes up to 6000 microvolts and polyphasia 50 per cent. Synchronisation was 40 to 50 per cent. The findings in the right biceps did not present any change from an examination performed prior to the onset of the new symptoms.

$$
{ }^{1} \text { Teca Corp., White Plains, N.Y. }
$$


4. Thirty-seven-year-old white male patient (D. B.) with a complete C6 tetraplegia from a fracture of $\mathrm{C}_{5}$ to $\mathrm{C}_{7}$ in August 1970 had good recovery and in 1974 had a normal muscle test and sensory examination above TI bilateral. Since then he has lost muscle strength in the distribution from $\mathrm{C}_{5}$ to $\mathrm{C} 8$ bilateral. Sensory level extended from TI to $\mathrm{C} 2-3$ on the right and $\mathrm{C} 8$ on the left. The patient had neck pain radiating to both upper extremities especially when bending the trunk forward. Air myelography showed an increase of the antero-posterior diameter at $\mathrm{C}_{3}$. Electrodiagnostic studies were performed twice, first in 1975 at which time there were normal nerve conductions. The electromyogram showed I to $2+$ fibrillation and narrow phasic polyphasia with normal duration. Amplitudes were up to 3500 microvolts. There was an interference pattern of 70 per cent. On two-channel electromyography there was no increase in synchronisation. This examination was not suggestive of syringomyelia. Repeat examination in March 1976 showed I to $2+$ fibrillation and fasciculations most marked in the right triceps. There was an increase of amplitudes up to 5000 microvolts and duration was up to $22 \mathrm{~ms}$. Polyphasia was 50 per cent. Synchronisation on two-channel electromyography was 95 per cent. Strength-duration curve of the deltoid was normal. Curve of the triceps showed a slight kink.

5. Forty-four-year-old white male patient (S. T.) who sustained a complete traumatic myelopathy at $\mathrm{T}_{5}$ in February 1973. In October 1974 the patient began having shooting pains around the $\mathrm{T}_{4}$ level radiating into both arms. He also had numbness in the left hand and face and showed depression of the right biceps and triceps deep tendon reflexes. There was dissociated sensory loss from $\mathrm{C}_{2}$ to $\mathrm{T}_{2}$ on the left and decreased muscle strength noted on the left side extending to $\mathrm{C}_{5}$. Air myelogram showed an increase of the antero-posterior diameter of the spinal cord suggesting a syrinx which was confirmed on surgery on I 4 June I976. Electrodiagnostic studies showed generalised normal nerve conduction study except for bilateral tardy ulnar palsies. Electromyogram showed $\mathrm{I}+$ fibrillation and fasciculation in the right biceps and triceps. There was an increase in potential duration up to $20 \mathrm{~ms}$. Polyphasia was 25 per cent and amplitudes were up to 5000 microvolts. On maximal effort there was recruitment of 80 to 90 per cent. Synchronisation was markedly increased. Strength-duration curves of the biceps and triceps showed a slight kink.

6. Fifty-five-year-old white male patient (E. O.) who received a traumatic left C6, right $\mathrm{C}_{5}$ incomplete sensory and motor myelopathy in 1953 . In the last 3 years the patient has shown increasing upper extremity weakness and also loss of ambulatory capabilities because of increasing leg weakness. The patient complained of an ice pack pressure' feeling on his back, head and neck. Air myelogram confirmed an increased diameter of the cervical cord suggestive of a syrinx which was confirmed on surgery on

\section{TABLE I}

Sensory nerve conduction

\begin{tabular}{lccccccc}
\hline Patient & \multicolumn{2}{c}{ Median } & & \multicolumn{2}{c}{ Ulnar } & & \multicolumn{2}{c}{ Sural } \\
\cline { 2 - 3 } & $\begin{array}{c}\text { Latency } \\
(\mathrm{ms})\end{array}$ & $\begin{array}{c}\text { Amplitude } \\
(\mu \mathrm{V})\end{array}$ & & $\begin{array}{c}\text { Latency } \\
(\mathrm{ms})\end{array}$ & $\begin{array}{c}\text { Amplitude } \\
(\mu \mathrm{V})\end{array}$ & $\begin{array}{c}\text { Latency } \\
(\mathrm{ms})\end{array}$ & $\begin{array}{c}\text { Amplitude } \\
(\mu \mathrm{V})\end{array}$ \\
\hline E. C. & $2 \cdot 5$ & 40 & $2 \cdot 2$ & 20 & $\mathrm{NT}$ & $\mathrm{NT}$ \\
B. D. & $2 \cdot 4$ & 45 & $2 \cdot 1$ & 22 & NT & NT \\
S. W. & $2 \cdot 4$ & 22 & $2 \cdot 2$ & 10 & $2 \cdot 6$ & 5 \\
D. B. & $2 \cdot 5$ & 25 & $2 \cdot 0$ & 18 & $2 \cdot 6$ & I5 \\
S. T. & $2 \cdot 6$ & 30 & $2 \cdot 1$ & 5 & $2 \cdot 5$ & I0 \\
E. O. & $2 \cdot 2$ & 50 & $2 \cdot 5$ & 20 & $2 \cdot 3$ & 20 \\
\hline
\end{tabular}


PAPERS READ AT THE ANNUAL SCIENTIFIC MEETING, I976
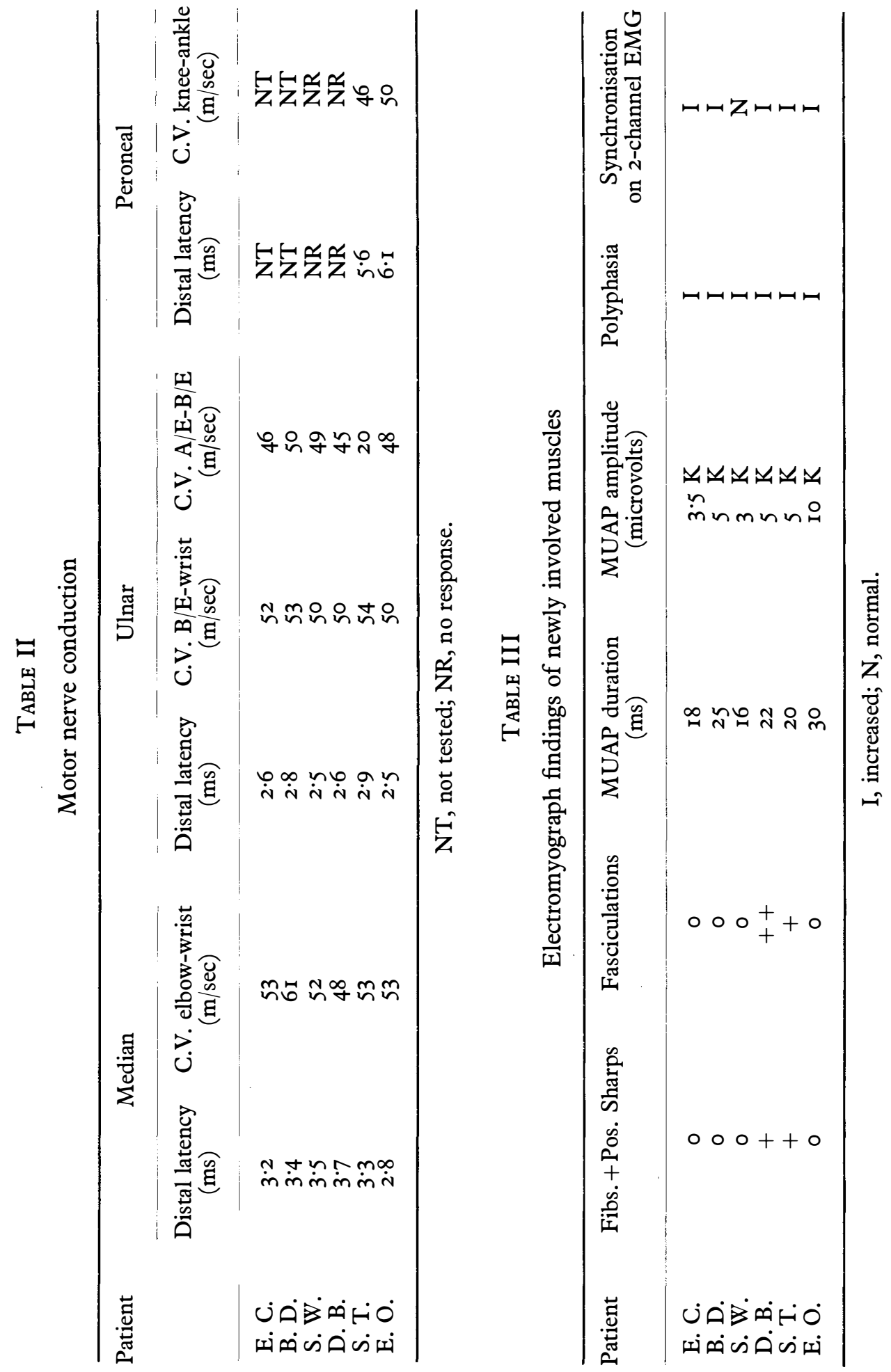

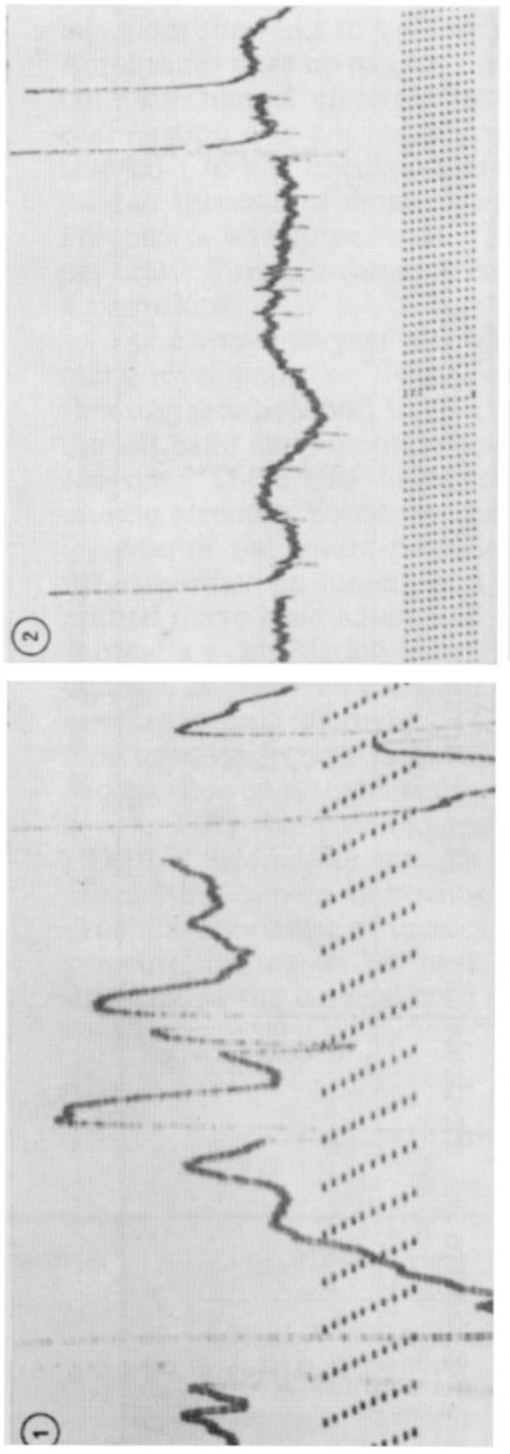
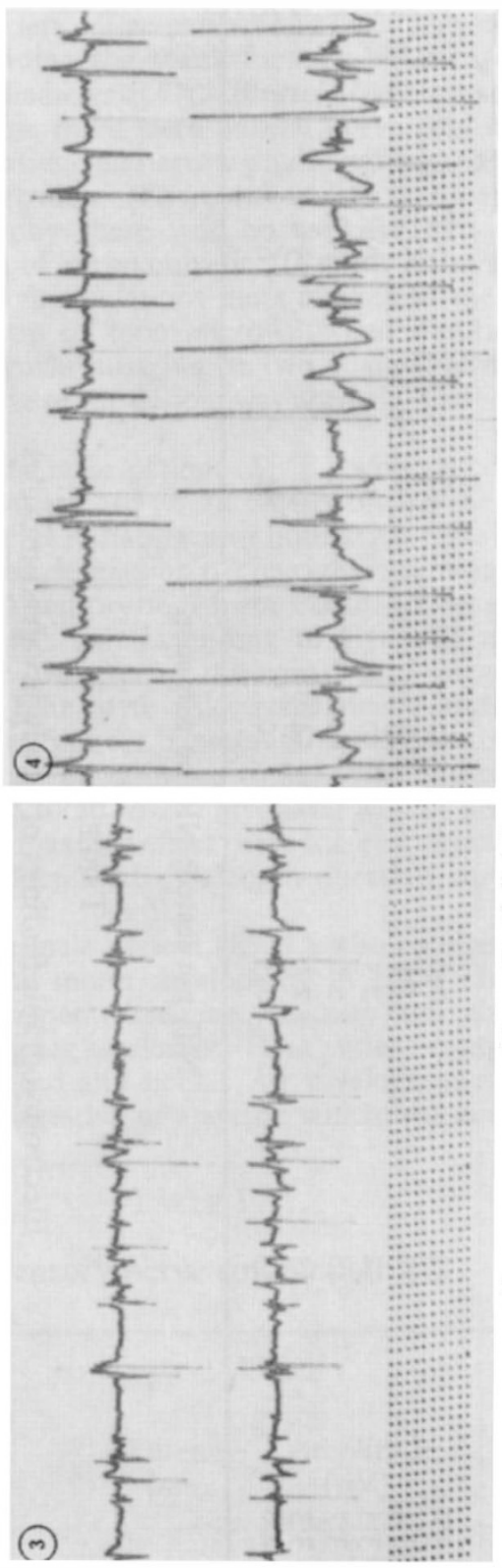

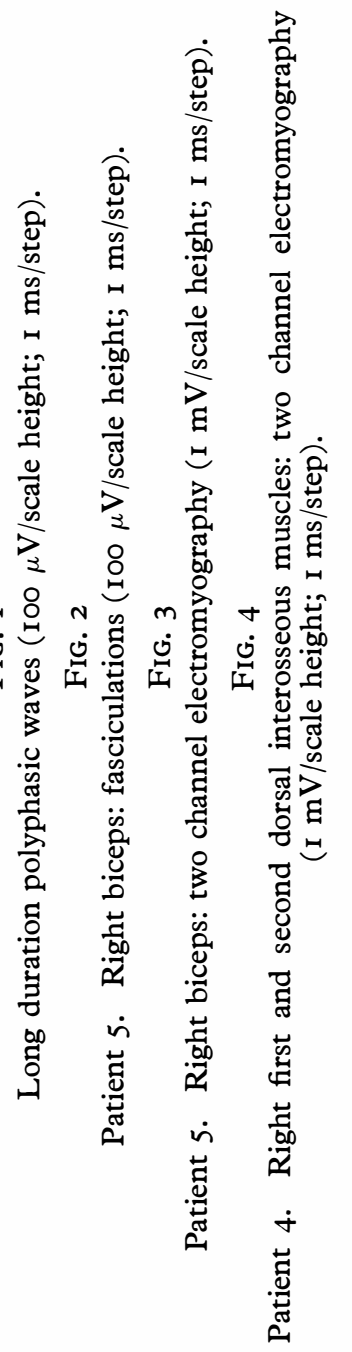


8 June 1976. Electrodiagnostic studies showed normal nerve conduction. Electromyography showed a general increase of potential duration up to $30 \mathrm{~ms}$ and amplitudes were up to 5000 microvolts. Polyphasia was 50 per cent. There were no spontaneous potentials observed. On full effort recruitment was 70 to 80 per cent. On two-channel electromyography there was a marked increase in synchronisation. Strength-duration curves were normal.

\section{Results}

Nerve conduction studies, sensory and motor, were all within the norm exccpe for subject No. 5 who showed markedly decreased amplitudes in both evoked ulnar nerve sensory potentials and slowing of the ulnar motor nerve conduction across both elbows (Tables I and II). Subjects 3 to 5 showed somewhat lowered evoked sensory potential amplitudes which is a common finding in spinal cord injury patients at least at certain times during their convalescence.

Electromyography. All patients exhibited increased polyphasia from 30 to 50 per cent and increased potential duration mainly up to $20 \mathrm{~ms}$ (Table III, Fig. I). Amplitudes were 5 to I0,000 microvolts in many of the involved upper extremity muscles. Spontaneous potentials, fibrillation, and positive sharp waves were observed only in nine muscles of two patients. Two patients showed fasciculations (Fig. 2). Increased synchronisation on two-channel electromyography was observed in all patients in the involved muscles even in some of those who showed clinically still normal strength (Figs. 3 and 4) except for patient No. 3. Strength-duration curves were normal except for three that showed minor kinks between ro and $3 \mathrm{~ms}$ (Fig. 5).

Patient No. 3 who was not found to have a syrinx showed no increase in synchronisation in the newly involved area (Fig. 6). The findings in the biceps and brachioradialis were present before the increase of symptomatology and were due to the anterior horn cell involvement at the level of the injury.

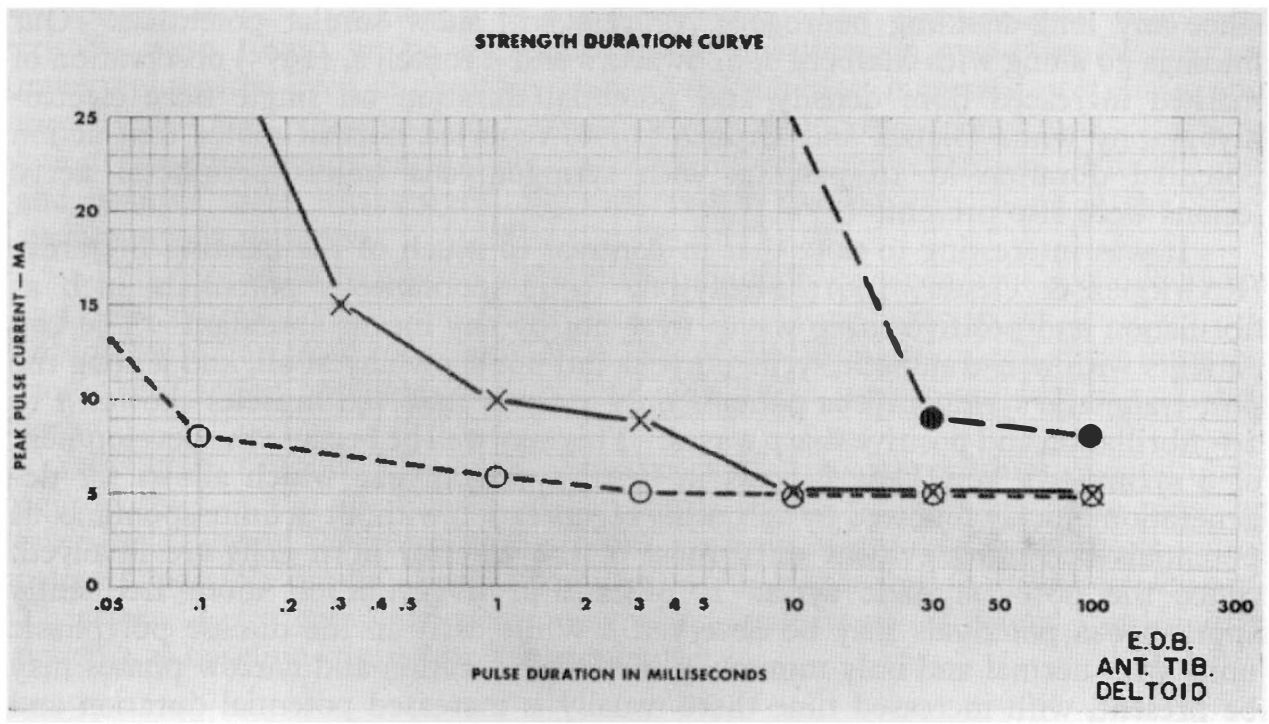

FIG. 5

Strength duration curves: $\bigcirc$, Normal; $\times$, Partial denervation suggested by 'kink'; $\bullet$, Denervation curve. 


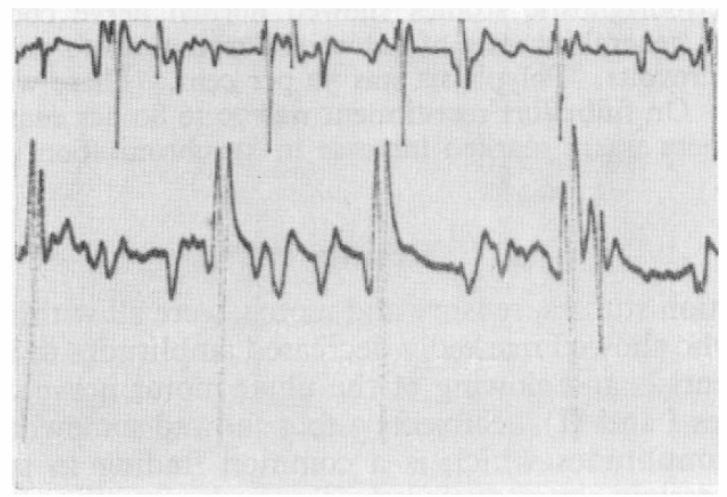

Fig. 6

Patient 3. Right trapezius: two channel electromyography from left to right.

\section{Discussion}

Nerve conduction studies were all within the norm as could be expected and is reported by Fincham and Cape (1968) except for one patient who showed bilateral tardy ulnar palsies. This apparently is not uncommon in patients with syringomyelia as observed by Jacobi and Krott (1975) who reported on Io patients out of 28 such involvement and Glatzel and Grünes (1976) in 7 out of I6 patients. Repeated microtrauma and neurogenic arthropathies were thought to be the cause. Jacobi and Krott (1975) felt that the ulnar palsy may well be an early finding in syringomyelia which certainly underlines the extreme importance of good and exact electrodiagnostic work-up. The electromyogram showed as most significant abnormalities an increase of polyphasia, potential duration and amplitude. While this is always suggestive of anterior horn cell involvement, it in itself is not diagnostic since any long-standing neurogenic process will show similar potentials. Our findings go along with Stalberg's, Schwartz's and Trontelj's, (1975) observation of marked increased fibre density and potential duration on single fibre electromyography while Glatzel and Grünes (1976) reported normal motor unit action potential duration in 16 patients with syringomyelia unless peripheral nerve lesions were also present.

It was interesting to note that in contrast to much of the existing literature (Rodriquez \& Oester, I96I; Finlayson, 1974) spontaneous potentials such as fibrillation and positive sharp waves were not by any means abundant. The two patients with non-traumatic syringomyelia did not show any at all, and among the post-traumatic syringomyelia patients only severely involved muscles showed I to $2+$ fibrillation and positive sharp waves. This may well be because the development of a syrinx is a very slow process in 'true' syringomyelia which allows for degeneration quickly followed by sprouting regeneration without definite spontaneous potentials becoming evident until most of the anterior horn cells are involved. Since the post-traumatic syrinx is quicker in its evolution more frequently spontaneous potentials may be observed. While early in the disease polyphasic units with normal and only minimally increased duration and narrow phases may be present, with increased time there usually is increased potential duration and few phasic polyphasic action potentials whose amplitudes may reach giant potential dimensions. Fasciculations, also always considered as a characteristic for anterior horn cell disease, were observed in many muscles of two patients with very high 
repetition. We have found the most helpful characteristic evidence suggesting anterior horn cell lesion to be the increased synchronisation in two channel electromyography. (All patients had normal electrolyte studies when the electrodiagnostic studies were performed.)

Strength-duration curves were not helpful except that in peripheral involvement there is an earlier sign of denervation than in anterior horn cell involvement. If a weak muscle with abnormal electromyogram, therefore, shows still a relatively normal SD curve, this may be suggestive of anterior horn cell disease.

The greatest difficulty that we encountered was in the two patients that had previously a cervical spine injury and after some recovery then presented with increasing symptomatology caused by a syrinx. Since the previous injury could have caused some increased synchronisation and typically large polyphasic action potentials, it was difficult to judge what was due to the new involvement caused by a syrinx formation. This certainly underlines the recommended necessity to study spinal cord injury patients electrodiagnostically early in their injury so that a good baseline exam can be reported and any change then be recognised more easily as representing new anterior horn cell involvement. In spinal cord injury patients the major differentiation is frequently from root irritation or compression syndromes. The best criteria to rule out radiculopathy is the lack of synchronisation on twochannel electromyography and also the generally less marked increase in amplitude and duration with polyphasics showing more narrow phases. Also the strengthduration curves have a tendency to show more abnormality than with anterior horn cell involvement. Compression syndromes may be recognised by nerve conduction abnormalities.

\section{SUMMARY}

Because of the frequently encountered difficulty in early diagnosis of a posttraumatic syrinx and the general lack of information available in the literature, electrodiagnostic studies of six patients are reported who were investigated for a symptom complex suggestive of syringomyelia. The most helpful diagnostic criteria were found to be increased synchronisation on two-channel electromyography often even in clinically uninvolved muscles, increased polyphasic and motor unit action potential duration with or without increased amplitude. Fasciculations were frequently encountered with high frequency repetition. Fibrillations and positive sharp waves were only observed in two patients, none in the 'true' syringomyelia patients.

This appears to be a major difference in findings between 'true' syringomyelia and post-traumatic syrinx most likely related to the time factor in the development. In differentiation from root irritation, a lack of synchronisation and short duration motor unit action potentials with normal amplitudes were significant in radiculopathy.

Because of reported frequent occurrences of osteoarthropathies causing ulnar neuropathies at the elbow and median nerve lesions at the wrist, care must be taken to delineate the respective nervous system lesions. In spinal cord injury patients, possible proximal nerve compression or root irritation must be ruled out. Therefore, early complete electrodiagnostic evaluations of spinal cord injury patients as baseline studies are recommended.

\section{RÉSUMÉ}

$\mathrm{Vu}$ la fréquence des difficultés posées par le diagnostic précoce des syrinx posttraumatiques et le manque d'informations dans la litérature, les auteurs rapportent les 
résultats de leurs examens électrodiagnostiques chez six patients présentant un tableau clinique complexe suggestif de syringomyélie.

Les critères diagnostiques les plus utiles se sont révélés être une plus grande synchronisation de l'électromyographie sur deux canaux, même pour des muscles cliniquement intacts, une augmentation des potentiels polyphasiques et une prolongation de la durée des potentiels d'action d'unité motrice, avec ou sans augmentation d'amplitude. Des fasciculations ont été fréquemment observées, avec une haute fréquence de répétition. Fibrillations et ondes positives n'ont été retrouvées que chez deux patients, dont aucun ne rentrait dans la catégorie des patients avec une 'vraie' syringomyélie.

Il semble y avoir une différence majeure entre les résultats observés dans les 'vraies' syringomyélies et dans les syrinx post-traumatiques, l'explication résidant plus que probablement dans le facteur développement dans le temps du processus pathologique. Défaut de synchronisation et potentiels d'action d'unité motrice de brève durée et d'amplitude normale sont quelques'uns des traits caractéristiques des radiculopathies.

La fréquence des arthropathies qui s'accompagnent de neuropathies au coude et de lésions du médian au niveau du poignet soulignent la nécessité d'un diagnostic différentiel des atteintes respectives du système nerveux.

Dans les lésions médullaires traumatiques, il est nécessaire d'éliminer la possibilité d'une compression nerveuse proximale ou d'une irritation radiculaire. Aussi semble-t-il indiqué d'avoir dans les myélopathies traumatiques des examens électrodiagnostiques précoces destinés à servir de ligne de base.

\section{ZUSAMMENFASSUNG}

Die häufige Schwierigkeit eine frühe Diagnose einer post-traumatischen Syringomyelie zu stellen und die karge Literatur auf diesem Gebiet, veranlasste uns, die elektrodiagnostischen Befunde von sechs Patienten zu berichten, die verdächtige Symptome auf Syringomyelie aufwiesen.

Das hilfreichste diagnostische Kriterium war hochprozentige Synchronie in zwei Kanal Elektromyographie, oft sogar in Muskeln, die klinisch noch keine Schwäche zeigten. Vielphasische und weite Muskelpotentiale mit oder ohne grössere Amplitude und Fascikulationen waren häufig. Spontane Potentiale (Fibrillationen und positive Wellen) wurden nur in zwei Patienten beobachtet; keine in den 'echten' Syringomyelitikern (ohne vorherige Rückenmarkverletzung). Dieser Befund ist unterschiedlich in den zwei Formen, höchstwahrscheinlich auf Grund der kürzeren Entwicklungszeit der post-traumatischen Syringomyelie. Nervenwurzelreizung unterscheidet sich von der Syringomyelie meistens durch schmalere drei und vielphasische Potentiale mit normaler Amplitude und das Fehlen der abnormalen Synchronie.

$\mathrm{Da}$ in Syringomyelie häufiges Auftreten von Median und Ulnarisparesen sekundär zu Osteoarthropathien oder Mikrotraumatisierung beobachtet wird, muss besonders beachtet werden, die verschiedenen Nervenschaden klar zu erkennen. In den Rückenmarkverletzten muss man proximale Nervenkompression oder Nervenwurzelreizung ausschalten. Deswegen empfehlen wir, frühzeitige vollkommene elektrodiagnostische Untersuchung auszuführen als Grundlage späterer Befunde, wenn Komplikationen auftreten.

\section{REFERENCES}

Barnett, H. J. M., Foster, J. B. \& Hudgson, P. (1973). Syringomyelia. W. B. Saunders, London, p. 318.

FinchaM, R. W. \& CAPE, C. A. (1968). Sensory nerve conduction in syringomyelia. Neurol. 18, 200.

Finlayson, A. J. (1974). Syringomyelia and related conditions. In: Clinical Neurology, Baker, A. B. (ed.), Baker, L. H. (assoc. ed.). Harper and Row, New York, Vol. 3.

GLATZEL, W. \& GRÜNES, J. U. (I976). Results of electromyographical and electroneurographical investigations concerning syringomyelia. Eur. Neurol. 14, 60.

JACOBI, H. M. \& KROTT, H. M. (I975). Ulnarisparesen bei Syringomyelie. Nervenartz, 46, 68.

MAGEE, K. K. \& SCHNEIDER, R. C. (1967). Syringomyelia: Loss of deep pain sensation with otherwise normal sensory perception. f. American Medical Association, 200, 795.

Martin, C. H. \& MAURY, M. (1964). Syndrome Syringomyélique Après Paraplégie Traumatique. A Propos de Six Cas de Syndrome Syringomyélique Cervical Survenant Dans des Paraplégies Dorsale Ou Lombaire. Presse Médicale, 72, 2839. 
Rodriquez, A. A. \& Oester, Y. T. (I96I). Fundamentals of electromyography. In: Electrodiagnosis and Electromyography, Licht, S. (ed.). E. Licht, New Haven, Connecticut, 2nd edition, p. 286.

Rossier, A. B., WERNER, A., WILDI, E. \& BERNEY, J. (I968). Contribution to the study of late cervical syringomyelic syndromes after dorsal or lumbar traumatic paraplegia. F. Neurol. Neurosurg., Psychiat. 3I, 99.

Stalberg, M. S., Schwartz, M. S. \& TrontelJ, J. V. (1975). Single fibre electromyography in various processes affecting the anterior horn cell. F. Neurol Sci. 24, 403.

Werner, A., Rossier, A., Berney, J. \& Zdrojewski, B. (1969). A Propos de Quatre Observations de Syringomyélie Cervicale Tardive Après Traumatisme Médullaire. Arch. Suisses Neurol., Neurochir. E Psychiat. 104, 77. 